\title{
Corporate Social Responsibility of Selected Businesses in Cebu City, Philippines
}

\author{
Niña Lyn Bueno', Jonathan O. Etcuban², Judy Ann Gimena ${ }^{3}$, Charito Bonghanoy ${ }^{4}$, \\ Reylan Capuno ${ }^{5}$ and Raymond Espina ${ }^{6}$ \\ ${ }^{1,3 \& 4}$ Faculty, University of Cebu, Cebu City, Philippines \\ ${ }^{2,5 \& 6}$ Faculty, Cebu Technological University, Cebu City, Philippines \\ E-Mail: buenoninalyn36@gmail.com, joetcuban@gmail.com, judygimena@gmail.com
}

\begin{abstract}
Corporate social responsibility (CSR) involves enhancing the personal satisfaction of the workforce and their families just as of the nearby network and society everywhere with the proceeding with responsibility by business to act morally and add to financial enhancement. This study determined the benefits of businesses from engaging in CSR programs. This study applied the descriptive method. This study utilized the researcher-made questionnaire to gather data on the characteristics of the business, the profile of the respondents as to years in the firm, the scope of activities of the CSR undertaken by the company and the benefits of the CSR towards the business enterprise. It was highly evident that the businesses undertook the following CSR initiatives or programs such as community development, information education, and teaching, environmental conservation and protection, and feeding program. It was also highly evident that the benefits that the business entity gained out of engaging in CSR programs or initiatives were positive public image and business sustainability. Moreover, it was also moderately evident that the other benefits gained from CSR were cost savings and tax incentives. The study concluded that the organizations that take social actions that are beneficial to the community, business society and the environment benefited from a myriad of dimensions such as improved public reputation and gained more patronage of its products and services that they offered. It was recommended that the proposed CSR model be adopted by the organizations that undertake various socially-beneficial initiatives.
\end{abstract}

Keywords: Social Science, CSR, Descriptive Method, Philippines

\section{INTRODUCTION}

The term Corporate Social Performance (CSP) has begun as an inclusive and global concept to include CSR, responsiveness, and the whole range of socially gainful exercises of organizations. It emphasizes the concern for corporate action and accomplishment in the social sphere. With a performance perspective, firms must formulate and implement social goals and programs as well as integrates ethical sensitivity into all making decisions, crafting policies, and taking actions.

Social obligation is a rule that anxieties the obligation of an organization to lead its undertakings morally in a way that benefits the two workers and the bigger society. In short, the concept of social responsibility presupposes the fact that a manager must strive to achieve societal as well as organizational goals. CSR is usually undertaken by a business entity with the desire to contribute good things for the welfare of the society. This means that the act of sharing corporate or business resources has a two-way impact on both the giver (business entity) and the receiver (community). To engage in CSR means that, in the normal operation of the business, a company is operating in ways that enhances society and the environment, instead of contributing negatively to it.

Several research studies have examined CSR and its effects on business performance, but their results vary widely. This comes from faulty analyses by way of regressing financial performance on corporate social performance, and perhaps from in adequately numerous controlled variables. Past examinations did not perceive wandering in innovative work as a basic variable in light of the fact that there is extensive practical down to earth proof to show that it has a generous positive effect on gainfulness. This misidentification makes one-sided appraisals of the money related effect of CSR (Chin-Huang et al., 2009).

So, when a business entity undertakes CSR initiatives, it will result in both benefits and costs. With the various advantages of CSR to the future sustainability of the business, the concern in this investigation is the associated costs in the implementation of its programs and activities to the target community or beneficiaries. The question now for the business entity is will the benefits of CSR outweigh the costs. The researchers have observed the rising number of companies and business enterprises who indulged in CSR for countless reasons. Foremost of these reasons is to be able to help the community where the company operates and be responsive to the needs of the society. However, every activity that is undertaken by the business entity required a budgetary requirement that has an impact on the profitability of the business enterprise. So, this investigation focuses on determining the effect of CSR on the overall sustainability of the socially inclined business entity.

\section{OBJECTIVES OF THE STUDY}

This study determined the benefits gained from the CSR among businesses in Cebu City, Philippines. The outcomes of this study were used as the basis for devising a CSR 
Sustainability Model. It answered the: 1) Characteristics of the business that undertake CSR; 2) Scope of activities of the CSR undertaken by the company; and 3) Benefits of the CSR towards the business enterprise as to public image, cost, tax, and business sustainability.

\section{METHODOLOGY}

This study applied the mixed method of research using both quantitative and qualitative data. It used a researcherdeveloped questionnaire to gather data on the characteristics, the profile of the respondents as to years in the firm, the scope of activities of the CSR undertaken by the company and the benefits of the CSR towards the business enterprise as to public image, cost, tax, and business sustainability. This study was conducted among the various business enterprises in Cebu that undertakes CSR initiatives. These business enterprises include various business entities across different forms of business organization, the nature of their business, the size of the firm, etc.

Cebu City is a first class highly developed city in the province of Cebu in Central Visayas, Philippines. The seat of government and capital for the provinces being governed independently and separately. The population as per 2015 Census was 922,611 making Cebu City the fifth most populated city in the nation and the most populated area in the Visayas. Cebu City is considered as the center of commerce, trade, and education in the Visayas. The respondents of the study who assessed the characteristics of the business, profile of the respondents as to years in the firm, scope of activities of the CSR undertaken by the company and the benefits of the CSR towards the business enterprise as to public image, cost, tax, and business sustainability were the key personnel who handle the CSR programs of the business enterprises. Thirty business entities in Cebu City who had been practicing CSR were surveyed with a respondent from each entity.

The researcher-developed survey tool was used to gather responses on the identified four dimensions of CSR as a sustainable model. The first two dimensions were determined from selection among given choices. The third dimension assesses the respondent's perception of the benefits of CSR towards the business enterprise in a range of choice. Also, the last dimension was gathered through a guided interview. The first section or block of information pertains to the characteristics of the business that undertakes CSR in Cebu as to form of business organization, nature of the business, years of operation, annual budget; and nationality. The second block pertains to the scope of activities of the CSR initiatives that were undertaken by the company or enterprises. The third block of information gathers data relating to the benefits of the CSR towards the business enterprise as to public image, cost, tax, and business sustainability. The questions were explained to them. Retrieval of the copies of the instrument was made after ten days. The accomplished copies of the questionnaire were collected, and the results were tabulated and interpreted using frequency, simple percentage, rank, weighted mean, and ANOVA.

\section{RESULTS AND DISCUSSION}

\section{A. Characteristics of Businesses that Undertake CSR}

Corporate duty is just a route for organizations to assume liability for the social and ecological effects of their business activities. A powerful CSR program is an open door for organizations to exhibit their great corporate citizenship and shield the organization from outsized hazard by taking a gander at the entire social and ecological circle that encompasses the organization. This section presents the data on the characteristics of the business enterprises regarding the forms of business organization, the nature of the business, years of operation, annual budget, and nationality.

TABLE I CHARACTERISTICS OF BUSINESSES THAT UNDERTAKE CSR ( $\mathrm{N}=30)$

\begin{tabular}{|c|c|c|}
\hline Indicators & Frequency & Percentage \\
\hline \multicolumn{3}{|c|}{ A. Form of Business Organization } \\
\hline Corporation & 23 & 76.67 \\
\hline Partnership & 4 & 13.33 \\
\hline Sole Proprietorship & 3 & 10.00 \\
\hline \multicolumn{3}{|c|}{ B. Nature of Business } \\
\hline Service & 20 & 66.67 \\
\hline Merchandising & 5 & 16.67 \\
\hline Manufacturing & 3 & 10.00 \\
\hline Hybrid & 2 & 6.67 \\
\hline \multicolumn{3}{|c|}{ C. Years of Operation } \\
\hline $1-3$ & 4 & 13.33 \\
\hline $4-6$ & 2 & 6.67 \\
\hline $7-10$ & 5 & 16.67 \\
\hline $11-13$ & 2 & 6.67 \\
\hline $14-16$ & 4 & 13.33 \\
\hline $17-20$ & 4 & 13.33 \\
\hline More than 20 & 9 & 30.00 \\
\hline \multicolumn{3}{|c|}{ D. Annual Budget (in PhP) } \\
\hline Less than $100 \mathrm{k}$ & 12 & 40.00 \\
\hline $100 \mathrm{k}-1 \mathrm{M}$ & 11 & 36.67 \\
\hline More than $1 \mathrm{M}$ & 7 & 23.33 \\
\hline \multicolumn{3}{|c|}{ E. Nationality } \\
\hline Domestic & 21 & 70.00 \\
\hline Foreign & 9 & 30.00 \\
\hline
\end{tabular}

The data contained in Table I show that out of the 30 establishments that were included in the study, majority or $76.67 \%$ are in the form of corporation, there were four or $13.33 \%$ who are in the form of partnership, while there were 
only three or $10 \%$ who are in the form of sole proprietorship. This indicates that the business entities that usually indulge in CSR projects of initiatives towards the chosen community or beneficiary are the big or large ones. Another reason for this is that any CSR activities would require budgetary outlay that will be an additional expense towards the business organization, so only the large businesses can afford to incur the additional expenses in undertaking different social programs and activities. As to the nature of businesses, the result indicates that since the economy of Cebu has overgrown with the influx of numerous investors and tourists from the different countries around the globe, the service industry or sector also grew. Concerning the years of business operations, the result denotes that those business entities that have the heart and concern towards the community and the environment are those huge and established ones and have penetrated in the market already.

Moreover, out of the 30 businesses that were included in this study, there were more entities whose budget allocation to its CSR programs and projects was less than one hundred thousand pesos (Php 100,000.00). Usually, these businesses indulged into less costly CSR activities like feeding programs, tree planting, coastal cleaning, and many more. Further, there were 11 or equivalent to $36.67 \%$ of the business entities' budget allocation to CSR was one hundred thousand to one million pesos (Php 100,000.00-Php $1,000,000,000.00)$ while it can be noted that seven organizations have a budget allocation to CSR initiatives for more than one million pesos (Php 1,000,000,000.00).

There are no strict guidelines about setting CSR Budgets. In any case, there is an agreement that says contributing benefits bodes well. In any case, most nations on the planet don't yet have an obligatory top on CSR, and in this manner CSR planning is regularly left to CSR experts to structure and persuade the board regarding why a financial plan is required.To sum up a CSR Budget that works for everybody, would resemble summing up a business spending that works for everybody, it doesn't, however pointers do exist that can guarantee being on the correct way to an extraordinary CSR spending plan and a $2 \%$ point is a decent begin. Everything relies upon organization type and size, net revenues, long haul versus momentary objectives, planning assets, possession, primary concern benefits and for the most part experimentation. A few organizations put a perfect measure of cash into CSR exercises, of them, some have expansive net revenues, and others have little net revenues - so how would they decide their financial plans? (Lieser, 2013). Regarding the nationality of the business, the data show that there were 21 businesses in this study that are classified as a domestic corporation, and there was only nine foreign-owned corporation consisting of $30 \%$. The reason why there were more domestic corporations is that the Philippine law restricts the foreigners to own majority shares of any corporation that are established under the Philippine laws, except for some industries that allow majority shares to be owned by foreign nationals.

According to Jenkins (2006) that while CSR has customarily been the area of the corporate division, acknowledgment of the developing centrality of the SME segment has prompted an accentuation on their social and ecological effect, shown by an expanding number of activities going for connecting with SMEs in the CSR plan. CSR has been all around explored in expansive organizations, yet SMEs have gotten less consideration. The consequences of this investigation exhibit a portion of the first objectives and standards expected to accomplish social obligation in SMEs, and start to give information that could be utilized to cause learning in different SMEs.Integrating CSR into the core of a company is crucial to its success. The study of Jenkins (2009) suggests how CSR can be built into a company's systems and become just the way we do things.

\section{B. Scope of Activities of the CSR Initiatives}

This section presents the data on the activities of the CSR initiatives being undertaken by the business entities that were covered in this investigation.

TABLE II SCOPE Of ACTIVITIES Of THE CSR UNDERTAKEN By THE BusinesSeS

\begin{tabular}{|c|l|c|c|c|}
\hline S. No. & \multicolumn{1}{|c|}{ Indicators } & Mean & Interpretation & Rank \\
\hline 1. & Community Development & 3.53 & Highly Evident & 1 \\
\hline 2. & Informal Education and Teaching & 3.50 & Highly Evident & 2 \\
\hline 3. & Environmental Conservation and Protection & 3.47 & Highly Evident & 3 \\
\hline 4. & Feeding Program & 3.37 & Highly Evident & 4 \\
\hline 5. & Aid to Small Businesses & 3.20 & Moderately Evident & 5 \\
\hline 6. & Financing & 3.20 & Moderately Evident & 5 \\
\hline 7. & Health Aid & 3.20 & Moderately Evident & 5 \\
\hline 8. & Legal Aid & 2.87 & Moderately Evident & 6 \\
\hline 9. & Social Infrastructures & 2.87 & Moderately Evident & 6 \\
\hline 10. & Livelihood Development and Assistance & 2.80 & Moderately Evident & 7 \\
\hline & Aggregate Mean & 3.06 & Moderately Evident & \\
\hline
\end{tabular}


It was highly evident that the businesses that undertake CSR conducted the following initiatives or programs: community development as indicated by the weighted mean of 3.53 , information education and teaching $(\mu=3.50)$, environmental conservation and protection $(\mu=3.47)$, and feeding program $(\mu=3.37)$. This means that the most common model of CSR program involves the people in the community so that their real needs will be identified and be addressed to ensure sustainability and continuous participation of the target community. However, there was less evidence that the business entities were indulged into the building of housing for victims of calamities or war $(\mu=2.43)$, and programs relating to rehabilitation of psychological aid to victims of crimes and violence $(\mu=2.43)$. Well, it is understandable that these CSR programs are costly to the company that is why there are only a few of them who can afford to undertake these initiatives.

The information suggests that this interdependency makes awareness of other's expectations in the psyches of network individuals alongside the overarching desires. For continuing this co-agent relationship, there is a requirement for Community Development (CD), which calls for joining forces activities with outer associations for engaging network individuals or partnership to enable people dependent on the goals of social equity and shared regard. Genuine advancement is encouraged when nationals from all strata of society connect with a feeling of network solidarity through joined procedures, projects, techniques, and exercises. According to Ismail (2009), CSR alludes to activities attempted by the network with an association with outside associations or company to enable people and gatherings of individuals by giving these gatherings the abilities they have to impact change in their networks. These aptitudes are frequently focused around making utilization of neighbourhood assets and building political power through the arrangement of huge social gatherings working for a typical plan. Network engineers must see how to function with people and how to influence networks' situations inside the setting of bigger social foundations. Compact disc is the way toward creating dynamic and practical networks dependent on social equity and common regard. It is tied in with impacting power structures to evacuate the obstructions that keep individuals from taking part in issues that influence their lives. The aggregate mean of 3.06 indicates that there was moderate evidence that the business organizations or companies various CSR projects to the different adopted communities. These communities usually compose who are marginalized or those who belong to the poverty threshold since CRS is done not for the high social class but to those who need help from those who have more.

According to Khan et al., (2012) that the companies not only have financial responsibilities but especially in conjunction of undesirable phenomena occurrence (as environmental pollution, unhealthy social concerns, waste of resources, etc.), they also have the social responsibilities plus those of the environmental protection area. The importance of concept is derived from the CSR. In order to deeply understand the concept, it may be referred to some useful terms in CSR describing, among which businesscompanies involvement in the community, corporate responsibility and sustainability can be mentioned.

\section{Benefits of the CSR towards the Business Enterprise}

This section presents the information on the data about the responses of the respondents on the benefits of the corporate social responsibility towards the business regarding the public image, cost, tax, and business sustainability.

TABle III Benefits Of The CsR Towards The Business EnTERprise As To Public IMAGE

\begin{tabular}{|c|c|c|c|c|}
\hline S. No. & Indicators & Mean & Interpretation & Rank \\
\hline 1. & $\begin{array}{l}\text { The CSR of the company improves company/business reputation and goodwill and } \\
\text { promotes patronage to the right/services offered by the company/business enterprise. }\end{array}$ & 3.67 & Highly Evident & 1 \\
\hline 2. & $\begin{array}{l}\text { The positive image of the company gained from the fame of its CSR initiatives } \\
\text { increases the popularity of the products and services offered by the business } \\
\text { enterprise. }\end{array}$ & 3.57 & Highly Evident & 2 \\
\hline 3. & Identification of human, financial, and physical resources by the plan. & 3.40 & Highly Evident & 3 \\
\hline 4. & $\begin{array}{l}\text { Promotion of desirable values towards the public as a CSR initiative program gain } \\
\text { support from investors and buying public/customers. }\end{array}$ & 3.37 & Highly Evident & 4 \\
\hline 5. & $\begin{array}{l}\text { Refraining doing actions that may harm the environment and usage of } \\
\text { environmentally harmful materials/products increases the positive image of the } \\
\text { business enterprises and gain product/service patronage from the public. }\end{array}$ & 3.30 & Highly Evident & 5 \\
\hline \multirow[t]{2}{*}{6.} & $\begin{array}{l}\text { Sponsoring socio-economic activities of the marginalized sectors, the company } \\
\text { increases the popularity and mobility of the products/services of the business } \\
\text { enterprise. }\end{array}$ & 3.27 & Highly Evident & 6 \\
\hline & Aggregate Mean & 3.43 & Highly Evident & \\
\hline
\end{tabular}

The result indicates that it was highly evident that the CSR of the company improves company/business reputation and goodwill and promotes patronage to the right/services offered by the company. In this indicator, this item no. lobtained the highest weighted mean. Though undertaking CSR activities the business entities or the company gained positive image from the target market and became the means in which these people patronize the products or the 
services that they offer. Most buyers concur that while accomplishing business targets, organizations ought to participate in CSR endeavors in the meantime (EpsteinReeves, 2010).Most customers trust that organizations doing philanthropy work will get a positive reaction (Sommerville, 2013). Somerville likewise discovered that shoppers are steadfast and willing to spend more on retailers that help philanthropy. Customers additionally trust that retailers moving neighborhood items will pick up steadfastness (Kardashian, 2013). Smith (2013) shares the belief that local marketing products will gain consumer trust.

On the other hand, the lowest mean of 3.27 indicates that sponsoring socio-economic activities of the marginalized sectors, the company increases the popularity and mobility of the products/services of the business enterprise. The data imply that organizations know about the significance of the general population, particularly their intended interest group, having a favorable view of them.

Apparently, their social obligation, above all else, is to convey great incentive for cash and give top-notch items and administrations, trailed by giving great after-deals bolster, client benefit, association in backings and community causes, and for the most part performing acts that show how the organization cares - about their clients, the earth, and the general public all in all.

The study of Lee and Shin (2010) finds out as CSR activities corporate social contribution, and local community contribution affects consumers' purchase intention while corporate environmental protection and contribution have no effects on consumers' purchase intention. The investigation of Idowu and Papasolomou (2007) proposes that organizations have distinctive purposes behind issuing CSR reports, for example; because of an expanding number of partners asking for data on CSR, organizations trust that doing as such is useful for business, to determine positive advertising benefits, to conform to the administration's demand for them to issue data on CSR.

\section{Benefits of the CSR towards the Business Enterprise as to Cost}

Table IV presents the data on the benefits of the CSR towards business enterprise as to cost.

TABLE IV BENEFITS Of THE CSR TOWARDS THE Business ENTERPRISE As TO COST

\begin{tabular}{|c|c|c|c|c|}
\hline S. No. & Indicators & Mean & Interpretation & Rank \\
\hline 1. & $\begin{array}{l}\text { In undertaking CSR programs of the business enterprises, it requires budgetary } \\
\text { outlay to carry the different activities. }\end{array}$ & 3.50 & Highly Evident & 1 \\
\hline 2. & $\begin{array}{l}\text { The community outreach activities as CSR initiatives increase the expenditure } \\
\text { of the business enterprise. }\end{array}$ & 3.13 & $\begin{array}{l}\text { Moderately } \\
\text { Evident }\end{array}$ & 2 \\
\hline 3. & $\begin{array}{l}\text { The practice of using energy-conserving materials/devices increases non- } \\
\text { environmentally harmful materials/products increases the entails additional } \\
\text { costs on the business enterprises. }\end{array}$ & 3.10 & $\begin{array}{l}\text { Moderately } \\
\text { Evident }\end{array}$ & 3 \\
\hline 4. & $\begin{array}{l}\text { The increases in sales from the right image through CSR offset the costs } \\
\text { incurred by the business enterprise in carrying out its business enterprise. }\end{array}$ & 3.03 & $\begin{array}{l}\text { Moderately } \\
\text { Evident }\end{array}$ & 4 \\
\hline \multirow[t]{2}{*}{5.} & $\begin{array}{l}\text { The cost of conducting Corporate Social Responsibility programs is negligible } \\
\text { compared to the positive image it brought towards the business enterprise and } \\
\text { the employees. }\end{array}$ & 3.03 & $\begin{array}{l}\text { Moderately } \\
\text { Evident }\end{array}$ & 5 \\
\hline & Aggregate Mean & 3.16 & $\begin{array}{l}\text { Moderately } \\
\text { Evident }\end{array}$ & \\
\hline
\end{tabular}

It was highly evident that in undertaking CSR programs of the business enterprises, which requires budgetary outlay to carry the different activities. Any activities that will be undertaken by the business organization in the community would incur additional expenses. On the other hand, the lowest mean of 3.03 indicates that it was only moderately evident that the increases in sales are from the right image through CSR that offsets the costs incurred by the business enterprise in carrying out its business enterprise. This means that that in many instances, but not all the time, the revenue generated out of the increase in the sales or revenues from the positive image and patronizing of the business and products outweighs the cost of carrying out various social activities that help the adopted community or the chosen beneficiaries.

Moreover, the aggregate mean of 3.16 shows that it was moderately evident that the businesses that engage in CSR programs and projects indeed benefit out from the rise in the revenue that offsets the cost or the expenditure incurred in the implementation of the CSR programs and activities. This result indicates that since the benefit is not in all cases, the businesses should continuously strengthen their CSR initiatives to ensure that the people will have upright perception towards them. As per Williamson et al., (2006) that business execution stresses cost decreases and productivity, while the business case complements the advantages to investors of good practices as their organizations turn out to be progressively appealing to partners and society. The SMEs endeavor to enhance business execution as a result of the weights put on them by market-overwhelmed basic leadership outlines. These edges don't urge SMEs to embrace deliberate activities to assist more extensive partners and society. CSR has advanced into a business resource of organizations, in which profit oriented administrators and business people are happy to 
contribute. This commodification of CSR has made it worthy in the business world, yet this comes at a significant cost from the point of view of the social obligation of business (Nijhof \& Jeurissen, 2010).

\section{E. Benefits of the CSR towards the Business Enterprise as to Tax Incentives}

Table $\mathrm{V}$ presents the data on the benefits of the CSR towards business enterprise regarding tax incentives.

TABLE V BENEFITS OF THE CSR TOWARDS THE BusinesS ENTERPRISE As TO TAX INCENTIVES

\begin{tabular}{|c|l|c|c|c|}
\hline S. No. & \multicolumn{1}{|c|}{ Indicators } & Mean & Interpretation & Rank \\
\hline 1. & $\begin{array}{l}\text { The decrease in the taxable income through the increase in the allowable } \\
\text { deduction for charitable contributions from the gross income is nothing } \\
\text { compared to the philosophy of being able to help the community. }\end{array}$ & 3.23 & $\begin{array}{c}\text { Moderately } \\
\text { Evident }\end{array}$ & 1 \\
\hline 2. & $\begin{array}{l}\text { The tax incentive enjoyed by the business enterprise out of its CSR program } \\
\text { entices more business to undertake activities that are beneficial to the } \\
\text { community. }\end{array}$ & 3.20 & $\begin{array}{c}\text { Moderately } \\
\text { Evident }\end{array}$ & 2 \\
\hline 3. & $\begin{array}{l}\text { The business undertakes CSR to be able to avail the allowable deductions of } \\
\text { the expenses in the conduct of its CSR programs from the gross income. }\end{array}$ & 3.13 & $\begin{array}{c}\text { Moderately } \\
\text { Evident }\end{array}$ & 3 \\
\hline 4. & $\begin{array}{l}\text { The increase in the allowable deductions increases the profitability of the } \\
\text { business enterprise. }\end{array}$ & 3.07 & $\begin{array}{c}\text { Moderately } \\
\text { Evident }\end{array}$ & 4 \\
\hline 5. & $\begin{array}{l}\text { The business enterprise contributes donations to the government's projects, } \\
\text { programs, and activities (PPPAs) in education, health, youth, and sports } \\
\text { development, human settlements, science and culture, and economic } \\
\text { development to avail the "full tax deductibility." }\end{array}$ & 2.87 & $\begin{array}{c}\text { Moderately } \\
\text { Evident }\end{array}$ & 5 \\
\hline & Aggregate Mean & 3.10 & $\begin{array}{c}\text { Moderately } \\
\text { Evident }\end{array}$ & \\
\hline
\end{tabular}

The data contained in Table $\mathrm{V}$ show that the weighted mean of 3.23 indicates that the decrease in the taxable income through the increase in the allowable deduction for charitable contributions from the gross income is nothing compared to the philosophy of being able to help the community. This item obtained the highest mean in this indicator of CSR benefits.

This means that there was moderate evidence that the social business organizations experienced the decline of their tax due to the government since they can declare their expenses incurred in undertaking CSR activities as non-taxable. As far as the incentives from the state are concerned, providing tax incentives for the programs of CSR and not just for actions related to culture would be a significant move. Thus, the existed disincentives, which concern both legislation and practice of public administration, central and regional, should be eliminated in the pursuit of CSR policies. At the same time, governments could play an essential role in encouraging and facilitating social and environmentally responsible business practices.

As far as the incentives from the state are concerned, providing tax incentives for the programs of CSR and not just for actions related to culture would be a significant move. Thus, the existed disincentives, which concern both legislation and practice of public administration, central and regional, should be eliminated on the pursuit of CSR policies. At the same time, governments could play an essential role in encouraging and facilitating social and environmentally responsible business practices (Geo, 2011). According to Christensen and Murphy (2004) that assess incomes are the backbone of vote-based government and the implicit understanding, yet most of global organizations have been organized to empower impose evasion in each ward in which they work. Organizations ought to embrace corporate social duty principles on tax assessment, including prerequisites to distribute all essential bookkeeping data and to shun the utilization of benefits washing vehicles made without generous monetary reason.

Garcia (2016) explores the degree to which the reputational impacts of CSR lead to expanded adequacy of corporate campaigning consumptions, as estimated by compelling duty rates. This intuitive impact makes a substantial monetary advantage for firms, and at last their proprietors, giving a chance to firms to address the interests of both nonproprietors and proprietors.

The examination uncovers that organizations with a high number of CSR qualities get a higher profit for their campaigning uses than firms with a high number of CSR concerns, reflected in lower residential compelling duty rates. This outcome proposes that the contending perspectives of the partner and investor hypotheses may not be as restricted as earlier writing has recommended. The money related advantages that can be picked up from being socially capable may result in primary concern benefits to the investors, while as yet tending to the requirements and wants of non-proprietor partners.

\section{F. Benefits of the CSR towards the Business Enterprise as to Business Sustainability}

Table VI presents the data on the benefits of the CSR towards business enterprise as to business sustainability. 
TABLE Vi Benefits Of THE CSR Towards The Business ENTERPRise As To Business SustainabiLity

\begin{tabular}{|c|c|c|c|c|}
\hline S. No. & Indicators & Mean & Interpretation & Rank \\
\hline 1. & $\begin{array}{l}\text { The CSR programs of the business ensure continued business in the long run due } \\
\text { to many patrons who share the same philosophy of helping a better community. }\end{array}$ & 3.60 & Highly Evident & 1 \\
\hline 2. & $\begin{array}{l}\text { The increase in sales out of the popularity of the business enterprise/company } \\
\text { through active CSR programs ensures that it has a reason to continue its } \\
\text { operations. }\end{array}$ & 3.37 & Highly Evident & 2 \\
\hline 3. & $\begin{array}{l}\text { The positive image out of undertaking CSR programs entices more investors in } \\
\text { the business enterprise. }\end{array}$ & 3.30 & Highly Evident & 3 \\
\hline 4. & $\begin{array}{l}\text { The CSR activities promote the products and services offered by the business } \\
\text { enterprise }\end{array}$ & 3.17 & $\begin{array}{l}\text { Moderately } \\
\text { Evident }\end{array}$ & 4 \\
\hline 5. & $\begin{array}{l}\text { The decrease in the tax liability of the business enterprises through tax incentives } \\
\text { given by the government increase its profitability for continuous business } \\
\text { operations. }\end{array}$ & 2.97 & $\begin{array}{l}\text { Moderately } \\
\text { Evident }\end{array}$ & 5 \\
\hline & Aggregate Mean & 3.28 & Highly Evident & \\
\hline
\end{tabular}

It was highly evident that the CSR programs of the business ensure continued business in the long run due to many patrons who share the same philosophy of helping a better community. This item obtained the highest weighted mean in this indicator. This result further denotes that in all cases the business enterprises that engage in CSR programs experienced long-term business continuity out from the increasing market share since the buyer manifest preferences on businesses that are socially-responsible, compared to those that are not. This benefit has encouraged or enticed more business organizations to undertake their CSR activities.

In any case, partners' low consciousness of and horrible attributions towards organizations' CSR exercises stay basic hindrances in organizations' endeavours to augment business profits by their CSR exercises, featuring a requirement for organizations to impart CSR all the more adequately to partners. Then again, the least weighted mean of 2.97 shows that there was moderate proof that the declines in the expense risk of the business undertakings through duty motivations given by the administration increment its benefit for nonstop business activities. This information suggests that in numerous examples the organizations increased more benefit because of the decrease in their assessment due because of the duty impetus permitted by the legislature.

Moir (2001) included that there have for quite some time been clashing desires for the idea of organizations' duties to society. In any case, for those organizations that do attempt what may be named CSR, what is socially dependable conduct rather than the executives of corporate picture the executives or other movement pointed overwhelmingly at business benefits?

\section{CONCLUSION}

As society is getting increasingly worried about the effective approaches of the organizations, society desires are expanding towards the social advancement of the organizations. Along these lines, it has turned out to be essential for the organizations to rehearse social duties to upgrade their picture in the general public. It is apparent that organizations that take social actions that are beneficial to the community, business society and the environment benefited from a myriad of dimensions such as improved public reputation and gained more patronage of its products and services that they offered. In this manner, the costs incurred in implementing various programs and projects are being offset by the benefit they gained from increased revenues. The government also offers proper means to reduce tax liability from any contributions and expenses related to CSR as an allowable deduction from their taxable income. Thereby, business sustainability can be assured in the long-run. Although organizations are taking genuine endeavors for the supported advancement, few commentators still are scrutinizing the idea of CSR. Some individuals guarantee that CSR underlies some future intentions while others think about it is a fantasy. CSR is not a strategy for brand building; in any case, it makes an interior brand among its workers. They are reveling into exercises that assist society and in one-way, or the other adds to the generosity of an organization.

CSR is the obligation of everybody i.e. business partnerships, governments, people in light of the following reasons: the income is earned just from the general public and in this manner it ought to be given back; accordingly riches is intended for use that is independent of anyone else and the general population; the essential intention behind a wide range of business is to extinguish the craving of the humankind all in all; the primary target of all business is to encourage individuals to patronize their products or services. CSR cannot be an extra additional - it must keep running into the center of each business morals, and its treatment of representatives and clients. Along these lines, CSR is turning into a quick creating and progressively focused field. The case for exhibiting corporate obligation is getting more grounded as desires among key supposition formers, clients and the general population is expanding. Being a decent corporate national is progressively essential for business achievement, and the key lies in coordinating open desires and needs, and in conveying inclusion and accomplishments broadly and successfully. 


\section{REFERENCES}

[1] Chin-Huang, L., Ho-Li, Y., \& Dian-Yan, L. (February 2009). The impact of corporate social responsibility on financial performance: Evidence from business in Taiwan. Technology in Society, 31(1), 5663. Retrieved from https://goo.gl/Q69WTr

[2] Christensen, J., \& Murphy, R. (2004). The social irresponsibility of corporate tax avoidance: Taking CSR to the bottom line. Development, 47(3), 37-44. Retrieved from https://goo.gl/r5htem

[3] Epstein-Reeves, J. (2010). Consumers overwhelmingly want CSR. Forbes.

[4] Garcia, J. (2016). The influence of corporate social responsibility on lobbying effectiveness: Evidence from effective tax rates. Retrieved from https://goo.gl/nGCxpS

[5] Geo, D. (2011). Tax incentives in corporate social responsibility. Global Conference on Innovations in Management. London. Retrieved from https://bit.ly/2EOyj9k

[6] Idowu, S. O., \& Papasolomou, I. (2007). Are the corporate social responsibility matters based on good intentions or false pretenses? An empirical study of the motivations behind the issuing of CSR reports by UK companies. Corporate Governance: The International Journal of Business in Society, 7(2), 136-147. Retrieved from https://goo.gl/ ozr7Y6

[7] Ismail, M. (2009). Corporate social responsibility and its role in community development: An international perspective. Journal of International Social Research, 2(9). Retrieved from https://goo.gl/ iosWox

[8] Jenkins, H. (2009). A business opportunity model of corporate social responsibility for small and medium sized enterprises. Business ethics: A European Review, 18(1), 21-36. Retrieved from https://goo. $\mathrm{gl} / \mathrm{xm} 9 \mathrm{CmF}$

[9] Jenkins, H. (2006). Small business champions for corporate social responsibility. Journal of Business Ethics, 67(3), 241-256. Retrieved from https://goo.gl/wp8DBj
[10] Kardashian, K. (2013). When retailers do good, are consumer more loyal? Tuck School of Business. Dartmouth, NH, USA. Retrieved from https://bit.ly/2ESkasI

[11] Khan, M. T., Khan, N. A., Ahmed, S., \& Ali, M. (2012). Corporate social responsibility (CSR)-definition, concepts, and scope. Universal Journal of Management and Social Sciences, 2(7), 4152.Retrieved from https://goo.gl/AJxvb5

[12] Lee, K. H., \& Shin, D. (2010). Consumers' responses to CSR activities: The linkage between increased awareness and purchase intention. Public Relations Review, 36(2), 193-195.Retrieved from https://goo.gl/fTXd7u

[13] Lieser, J. (2013). Budgetting on CSR: Make it a rewarding investment beyond monetary valuations. CSR Lebanon. Retrieved from https://bit.ly/2Amfc3t

[14] Moir, L. (2001). What do we mean by corporate social responsibility? Corporate Governance: The international journal of business in society, 1(2), 16-22. Retrieved from https://goo.gl/ PDZDEc

[15] Nijhof, A. H., \& Jeurissen, R. J. (2010). The glass ceiling of corporate social responsibility: Consequences of a business case approach towards CSR. International Journal of Sociology and Social Policy, 30(11,12), 618-631. Retrieved from https://goo.gl/8L6Vaf

[16] Smith, N. (2013). Corporate social responsibility: Power to the people. Marketing Week. Retrieved from https://bit.ly/2EPRhNG

[17] Sommerville, M. (2013). Nearly half of Britons would buy more from a store that supports charity, Retail Gazette. Retrieved from https://bit.ly/2QUNoNR

[18] Williamson, D., Lynch-Wood, G., \& Ramsay, J. (2006). Drivers of environmental behaviour in manufacturing SMEs and the implications for CSR. Journal of Business Ethics, 67(3), 317-330. Retrieved from https://goo.gl/TYtqVx 